\title{
Boundedness dan Polusi pada Situs Islam Cirebon Abad XVI-XVIII
}

\author{
Irmawati.M-Johan
}

\begin{abstract}
Archaeological sites are the traces of people's lives in the past. The remaining traces are texts, simply waiting to be read. This article tries to interpret the housing patterns in the sites of palaces in Cirebon using the concepts of boundedness, the sacred, the profane, and the pollution.
\end{abstract}

KEYWORDS Archaeology, boundedness, pollution

Boundedness adalah sebuah konstruksi batas konseptual antara dua tempat atau dua kualitas, seperti antara sacred dan profane (Conkey 1982; Shanks dan Tilley 1982, Dark 1995:149). Boundedness dapat direfleksikan dalam batas-batas fisik, seperti yang sudah dilakukan oleh Fleming (1982). Ia adalah pionir dalam mengkaji korelasi antara batas-batas fisik dengan batas-batas konseptual. Kajian seperti itu telah dikembangkan menjadi studi yang lebih luas lagi, yakni melihat batas-batas fisik sebagai simbol dari batas-batas konseptual. Studi ini memiliki dasar pemikiran bahwa batasa-batasan konseptual memiliki korelasi secara fisik. Oleh karena itu, hal itu dapat dikenali di dalam arkeologi. Konsep boundedness telah diterapkan dalam kajian mengenai pembagian rumah tinggal, dan khususnya tentang pemukiman, seperti yang dilakukan Bowden dan McOrmish (1983) serta Hingley (1984) (Dark 1995:149). Di dalam arkeologi religi, terutama dalam kajian mengenai gereja-gereja Kristen, boundedness sudah dikenal. Misalnya, denah gereja dan pagar keliling dapat dilihat sebagai pemisahan antara bagian yang profan dan bagian yang sakral (Dark 1995:150).

Studi tentang boundedness dikaji dalam arkeologi sosial seperti yang dilakukan Fleming (1982). Ia berpendapat bahwa batas-batas sosial (kelas) tercermin dalam batas-batas fisik.Demikian pula pendapat yang diajukan Whitelaw (1983), dalam penelitiannya tentang masyarakat peramu, bahwa jarak fisik dalam pola pemukiman adalah representasi jarak sosial (lihat Dark 1995: 98-99). 
Selain boundedness, konsep polusi juga penting untuk memahami masalah social space dalam suatu masyarakat. Dalam studi antropologi banyak penelitian mengkaji bahwa setiap masyarakat memiliki konsep yang berbedabeda mengenai bersih dan kotor. Hal itu berkenaan dengan persepsi yang sudah mengakar, yakni mengenai maksud bersih dan kotor. Polusi dapat berbentuk apa saja. Polusi fisik adalah kondisi fisik yang dianggap kotor, seperti kotoran dari badan atau najis. Selain itu, ada yang dinamakan polusi ritual. Polusi ritual adalah ketika ada kotoran yang berasal dari sesuatu yang dianggap tidak bersih dalam pengertian agama, seperti larangan mengonsumsi babi pada masyarakat Islam dan Yahudi (Dark 1995:151).

Arkeologi memandang perlu mengetahui bilamana masyarakat masa lalu menganggap sesuatu adalah kotor. Misalnya masyarakat Yunani dan Romawi kuno beranggapan bahwa upacara penguburan adalah ritual yang terpolusi. Oleh sebab itu, kuburan tidak boleh berada di dalam situs permukiman dan situs agama karena keduanya harus dijaga kesuciannya (Dark 1995: 151).

\section{RUANG DAN RituAl KEMATIAN}

Praksis kematian tidak selalu harus dilihat sebagai mikrokosmos dari suatu organisasi social, tetapi dapat juga dilihat sebagai ekspresi materi dan sebagai perwujudan hubungan ideal yang diformulasikan antara yang mati oleh individu yang berbeda atau antarkelompok-kelompok dalam masyarakat. Semua evidensi (evidence) arkeologi dibuat atas dasar hubungan dan asosiasi antara sistem simbol yang berbeda-beda. Hubungan itu, diekspresikan dalam bentuk materi, dan merupakan konstruksi sosial dan suatu klasifikasi kategori. Menurut Pearson (1982), praksis kematian di Inggris dari abad ke-19 hingga abad ke-20 memeperlihatkan perlakuan terhadap yang mati berdasarkan hubungan-hubungan seperti ini. Ada dua katagori pada ritual kematian yang dilihat yakni, (1) kategorisasi penempatan yang mati oleh yang hidup dan (2) bagaimana yang mati digunakan sebagai salah satu alat social advertisement antarkelompok yang bersaing.

Atas dasar itu dapat dilakukan beberapa cara pengamatan untuk melihat hubungan antara yang hidup dan yang mati pada situs-situs arkeologi, yaitu melihat aspek spasial dan kedudukan topografi dari yang mati. Batas-batas yang dipakai untuk memisahkan tempat yang mati dan yang hidup, tidak hanya sungai, pagar kawat, tetapi juga jarak spasial, seperti penempatan yang mati di atas bukit.

Hubungan tempat kediaman fisik antara yang hidup dan yang mati. Misalnya tempat tidur, rumah, settlement, pemukiman, tempat sampah. Berapa banyak energi yang dikeluarkan untuk tempat yang mati dibandingkan dengan tempat yang hidup. Kemudian perbedaan antara yang mati baik dalam peran dan asal-usul kelompoknya yang diekspresikan dalam ritual kematian dengan artefak yang khusus berkaitan dengan yang mati terkait dengan alat senjata yang ikut dikubur dan dengan alat lainnya yang tidak ikut dikubur tetapi diwariskan. 
Faktor-faktor tersebut berakibat pada cara yang mati dilihat dalam konteks social advertisement. Kelompok sosial mana yang berkompetisi (keluarga, tetangga) dan dengan cara bagaimana kompetisi ini dapat diterima (bagaimana bila dibandingkan dengan kekayaan pribadi dan kekuasaan, seperti desain rumah, pakaian perhiasan).

Penelitian Pearson melihat perubahan dalam simbol ritual kematian. Perubahan hubungan yang hidup dengan yang mati dapat dijelaskan dengan mengganti agency control social tradisional (agama) dengan tatanan baru, yaitu agency rationalism, science, medicine dalam kerangka kapitalisme (Pearson 1980: 110). Pengurangan upacara dan bangunan monumental, seperti juga peningkatan pengkremasian, dapat dijelaskan dengan cara itu. Jenazah dilihat sebagai sesuatu yang tidak diinginkan dan harus dimusnahkan dengan cara yang higienis dan efisien.

Dalam pada itu, konsep spasial dilihat sebagai katagori yang mengatur pola perilaku yang menjadi dasar penyesuaian diri dari semua makhluk manusia. Hal itu melibatkan dimensi pengalaman yang mendasar dan sebagai kondisi yang dibutuhkan untuk kematangan fisik dan kehidupan sosial. Tanpa kemampuan tentang persepsi ruang, orientasi spasial, dan manipulasi konsep spasial, manusia tidak dapat menyelaraskan aspek lain dari perilakunya dengan sesama manusia dalam kehidupan sosialnya (Halowell 1980: 131).

Untuk dapat memahami kaitan antara ruang dan manusia, kita dapat mengamati pendapat yang dikemukakan oleh Gibson dalam Halowell, yakni ruang diciptakan dengan variabel yang sama dengan benda; permukaan dan margin yang terlihat bukanlah udara; dan ruang harus diisi agar terlihat. Ruang kosong adalah abstraksi. Selanjutnya, ia membedakan antara literal perception dan perception Schematic. Literal perception merupakan persepsi subtansi atau dunia spasial, misalnya dunia warna, tekstur, permukaan, ujung, bentuk interspasial. Sementara itu, persepsi schematic yaitu persepsi tentang kegunaan dan signifikansi dari benda-benda yang biasa menyertai kita (lihat Halowell 1980: 132).

Selanjutnya, Halowell menegaskan bahwa manusia memiliki kemampuan untuk mencapai tingkat organisasi psikologis yang memungkinkan "persepsi tentang self" sebagai objek dalam dunia objek selain self. Kesadaran tentang diri yang tidak dibawa sejak lahir tetapi sebagai skema tradisional yang menjadi titik referensi ditemukan dalam budaya atau dalam perbendaharaan referensi spasial. Dengan demikian, harus ada kesadaran yang konstan dari berbagai relasi antara self dan objek dalam skema spasial sehingga budaya menjadi faktor penting dan merupakan bagian yang tidak terpisahkan dari dunia "keruangan" tempat manusia berperan. Pemberian nama tempat, namanama bintang, peta, mitos dan cerita, arah hadap bangunan, implikasi spasial dalam tarian dan upacara, semuanya merupakan konstruksi dan menjaga pola spasial dunia tempatnya hidup dan bertindak (Halowell 1980: 133).

Di akhir uraiannya, Hallowell menyimpulkan bahwa manusia di mana pun berada memiliki konsep kosmis, ia diarahkan ke dunia yang memiliki dimensi spasial. Manusia mengetahui di mana tempat si mati dan sesuatu 
tentang hal walaupun tidak pernah melihatnya secara langsung. Tuhan dan jiwa diberi tempat kediaman dan bergerak di dalam ruang, mereka tidak hanya dianggap ada tetapi juga ada di suatu tempat. Manusia dalam berbagai budaya telah membentuk kerangka spasial yang meliputi tempat yang terjauh dan terdekat, hal-hal spiritual dan keduniaan, wilayah-wilayah alam semesta (Hallowell 1980: 134-135).

\section{Situs Cirebon sebagai Teks}

Botscharow (1991: 53) dalam penelitiannya tentang masyarakat Mousterian di Eropa menjelaskan bahwa masyarakat Maousterian telah membagi ruang "hidupnya" dengan memperlihatkan katagorisasi antara yang hidup dan yang mati. Dalam hal ini, kuburan dilihat sebagai "batasan" antara yang mati dan yang hidup. Jika yang mati tidak dikubur akan membingungkan dalam pembuatan kategori jiwa; mereka ada di sini tetapi juga hilang, tentang manusia yang hidup dan juga yang "refuse". Mereka (yang mati) harus ditempatkan pada tempatnya dan tidak bersama-sama dengan yang hidup. Banyak tempat untuk menyimpan yang mati sebagai cara untuk memisahkannya dari yang hidup. Sangat mungkin untuk membedakan antara yang mati dan yang hidup. Salah satu caranya adalah mengubur. Penelitian di situs Mousterian memperlihatkan bahwa masyarakat Maosterian telah memberlakukan perbedaan ruang, antara yang hidup dan yang mati, living space dan refuse space, dan antara activities area dan living space (Botscharow 1991: 53).

Pembacaan katagori yang merupakan cultural code, seperti yang dilakukan pada masyarakat Maousterian, diterapkan dalam penelitian pada teks yang lain, yaitu Situs Keraton Kasepuhan, Keraton Kanoman dan Keraton Cirebon di Cirebon, Jawa Barat.

\section{Hir arki Spasial di Situs Ker aton}

Cirebon dalam kenyataannya memiliki tiga buah keraton yang merepresentasikan tiga pemilik kekuasaan yang menguasai dan mengatur wilayahnya masing-masing (lihat peta no. 1). Berdarkan data sejarah, Cirebon didirikan oleh seorang wali bernama Sunan Gunung Jati. Setelah Sunan Gunung Jati meninggal, kekuasaan diwariskan kepada Panembahan Ratu. Setelah Panembahan Ratu meninggal (1650), tahta diberikan kepada Pangeran Girilaya yang berputra tiga orang, yaitu pertama Pangeran Martawijaya yang menjadi Sultan Sepuh I di Kasepuhan; kedua, Pangeran Kertawijaya yang menjadi Sultan Anom I; dan ketiga, Pangeran Wangsakarta yang menjadi Panembahan Cerbon I (Tjandrasasmita 1999: 287).

Kraton, sebagai tempat tinggal raja, secara garis besar memiliki pola yang relatif sama. Di kompleks keraton Cirebon, ruang dibagi dua yang berbeda atas dasar kegunaannya, yaitu antara tempat tinggal dan yang bukan tempat tinggal. Kedua ruang itu dibatasi dengan tembok keliling keraton. Area di dalam tembok kraton sebagai tempat tinggal dan di luar tembok keraton sebagai bukan tempat tinggal. Selain itu, ada katagorisasi yang terjadi antara laki-laki dan perempuan. Ruang perempuan adalah dapur. Perempuan 
bertugas untuk menyiapkan makanan dalam upacara Maulud Nabi. Ruang untuk laki-laki adalah Langgar Agung. Para Lelaki bertugas membaca doa di Langgar Agung (Siddique 1987: 132-133).

\section{HiR arki SPASIAl di Kompleks MAKam}

Kompleks makam yang terletak kira-kira $5 \mathrm{~km}$ ke arah utara kota Cirebon merupakan bukit yang diberi nama Gunung Sembung (lihat peta 1). Kompleks makam tersebut terdiri dari sembilan tingkat, pada tingkat IX ini terdapat bangunan yang dinamakan Jinem, tempat makam Sunan Gunung Jati beserta istri dan keluarganya yang terdekat. Pada tingkat VIII ke bawah terdapat (1) makam raja-raja setelah Sultan Sepuh I dan (2) jalan pemisah antara kuburan sebelah timur (kanan), yang merupakan kuburan Kasepuhan dan Kecerbonan, dan kuburan sebelah barat (kiri) yang merupakan kuburan dari raja-raja Kanoman. (lihat denah no.1). Menurut Tjandrasasmita (1999) jalan pemisah antara kubur raja Kasepuhan dan raja Kanoman merupakan refleksi dari perpecahan politis di antara penguasa Cirebon Pasca-Sultan Girilaya (wafat 1650) (Tjandrasasmita 1999: 285-300).

Ziarah kubur bagi golongan umum hanya diperkenankan hingga pintu di tingkat III (pintu Pasujudan), sedangkan raja dan keturunannya boleh mencapai tingkat IX. Pembatasan seperti ini, menurut Sharon Siddique, berkaitan dengan "kedekatan" dengan tokoh suci, tempat suci dan benda suci (pusaka) sehingga memperlihatkan "kedekatan" dengan Tuhan. "Kedekatan" dengan yang serba suci ini merupakan simbol yang menguatkan kekuasaan statusnya sebagai penguasa tertinggi (Siddique 1987: 182). Kompleks makam ini, selain perbedaan antara yang hidup dan yang mati, antara Barat (kiri) dan Timur (kanan), memperlihatkan pula perbedaaan antara yang profan dan sakral.

\section{Kategori Sosial di Situs MaKam}

Kematian dalam Islam, menurut Peacock (1978: 84), adalah pergantian kehidupan, sedangkan Hasan Muarif Ambary (1998) berpendapat bahwa kematian adalah berpisahnya atau tercabutnya ruh atau jiwa dari badan. Setelah itu, seseorang menuju ke Alam Kubur dan ruh tersebut kemudian dibangkitkan untuk mengikuti suatu pengadilan untuk menentukan tempat kehidupan abadi (surga atau neraka). Surga digambarkan sebagai tempat yang penuh dengan kebun, buah anggur, gelas yang penuh berisi minuman (Q.S. Al-Naba: 32-34 ), yang mengalir di bawahnya sungai (Q.S. Al-Taghabun: 9), diedarkan piring emas dan piala serta segala apa yang diinginkan oleh hati (Q.S. Al-Zukruf: 71), di mana para penghuninya bertelekan di atas permadani sutra, ada bidadari yang sopan menundukkan pandangannya (Q.S. AlRahman: 54-55), berada di atas dipan bertahtakan emas dan permata yang dikelilingi oleh anak muda yang tetap muda (Q.S. Al-Waqi'ah: 15-17), dan sebagainya. Sebaliknya, neraka digambarkan sebagai tempat berlakunya siksa yang pedih dengan api yang menyala-nyala, seburuk-buruk tempat kembali (Q.S. Al-Nisa: 18,55,115), seburuk-buruk tempat kediaman (Q.S. Al-Ra'd: 18), 
penghuninya selalu memakai pakaian api neraka, dan air panas penghancur isi perut (Q.S. Al-Haj: 19), dan sebagainya (Ambary 1998: 96 - 97; Woodward 1999: 255).

Di Jawa dan di Negara berpenduduk mayoritas Muslim, pengkultusan terhadap para wali merupakan unsur sentral dalam agama rakyat. Para wali mempunyai kekuasaan untuk memberi berkah dan membantu mereka yang mempunyai masalah keduniawian dan keagamaan. Di kalangan orang Jawa, keramat adalah kata sifat yang mencirikan religius para wali. Keramat biasanya berupa makam suci. Tempat keramat lain bagi wali dapat menjadi tempat memohon. Keramat hanya dapat diperoleh melalui penyucian jiwa dan dijadikan hubungan untuk mendekatkan diri dengan Tuhan (Allah). Kebanyakan kesaktian para wali berasal dari kemampuan mereka untuk memohon pengampunan atas nama Allah bagi orang yang tingkat pencapaian spiritualnya rendah (Woodward 1999: $251-253$ ).

Sunan Gunung Jati yang telah meninggal dianggap tetap hidup dan tinggal di makam ini. Seluruh kompleks pun diperlakukan sebagaimana layaknya sebuah tempat kediaman wali. Untuk mengurusi makam, dibentuklah kepengurusan yang terdiri dari jeneng sebagai kepala administrasi, penghulu sebagai pimpinan mesjid, 12 orang kaum mesjid, pembantu penghulu, bekel tua berjumlah empat orang, pembantu Jeneng, bekel anom berjumlah 8 orang yang bertugas untuk merawat makam Sunan Gunung Jati dan 108 orang wong kraman yang bertangung jawab untuk memelihara kompleks makam, dan seorang juru kunci. Seluruh pengurus dirotasikan dalam beberapa kelompok dan masing-masing beranggotakan 15 orang. Adapun jeneng, penghulu, bekel tua, dan bekel anom diangkat oleh Sultan Kasepuhan dan Kanoman. Jeneng harus keturunan patih keeling, sedangkan pengurus lain harus keturunan dari pengikut patih keling (Siddique 1977: 104-5).

Berdasarkan berbagai ritual, makam Sunan Gunung Jati sebagai tempat yang dianggap suci. Dipercayai bahwa jika seseorang melakukan "meditasi" di tempat tersebut, dia menjadi" dekat "dengan Sunan Gunung Jati dan melalui wali itu seseorang dapat menuju kepada Tuhan (Siddique 1977: 182). Demikian pula dengan benda-benda pusaka yang dimiliki Sunan Gunung Jati. Sebagai tempat yang paling suci makamnya hanya boleh diziarahi oleh keturunannya langsung. Selain itu, jimat yang paling suci adalah Panjang Jimat, piring porselin Cina yang dianggap sangat keramat dan hanya digunakan pada upacara Maulud di Keraton Kasepuhan yang hanya boleh disentuh oleh keturunan dari Sunan Gunung Jati dan kerabatnya. Baik makam Sunan Gunung Jati dan pusaka panjang jimat dianggap memiliki kekuatan. Berkah merupakan pemberian yang istimewa dari Tuhan. Para Wali adalah para pemilik berkah. Berkah tidak ikut mati ketika mereka (para wali) meninggal. Berkah diwariskan kepada keturunannya dalam bentuk warisan spiritual. Berkah ini juga tetap ada hingga saat ini pada makam wali dan juga pusakanya. Dengan demikian, sultan dan keluarganya dapat mempertahankan dan memperkuat statusnya di puncak kekuasaan di hadapan rakyatnya (Siddique 1977: 182-3). 
Selain konsep berkah, seorang wali juga dianggap sebagai insan kamil (manusia sempurna) yang dikenal dalam ajaran tasawuf. Ia sebagai cermin yang sempurna. Dalam ajaran tasawuf, manifestasi realitas ada yang lahir dan yang batin. Proses mendasar dari yang lahir menuju ke yang bathin ini difasilitasi dengan kehadiran wali yang telah menjadi insan kamil, dan wali inilah yang membawa pada dirinya "sinar Muhammad" (Siddique 1977: 178).

Konsep keramat, menurut Woodward (1999: 254-255), menjadi dasar kepercayaan yang berkaitan dengan hidup sesudah mati dan kultus kematian. Jiwa setelah mati berada di suatu alam yang berbeda dengan alam dunia dan tempat itu dinamakan alam barzakh, tetapi, menurut pendapat lain, roh itu tetap berada di kuburan yang memungkinkan mereka untuk berhubungan dengan orang hidup (Woodward 1999: 256). Pandangan itu banyak didukung pula oleh hadist, salah satunya adalah:

"Tidak seorang pun dari kamu yang lewat kuburan saudara Muslimnya yang ia tahu di dalam bumi dan memberinya salam kecuali bahwa orang yang mati itu mengakuinya dan mengembalikan salam itu kepadanya" (Smith dan Haddad 1981:51).

Al-Ghazali juga sependapat bahwa jiwa orang yang mati tetap berada di kuburannya selama dua atau tiga bulan. Setelah itu, terbang ke surga taman burung (Woodward 1999: 257). Keberadaan jiwa para wali tidak sama dengan keadaannya, mereka dipercaya berdiam di kubur mereka dan sekaligus juga di surga. Mereka diberi pilihan untuk tinggal di salah satu dari tujuh surga atau tetap di dalam kuburan hingga hari pengadilan (Woodward 1999: 257).

Kuburan di kompleks makam Sunan Gunung Jati memperlihatkan bahwa terdapat perbedaan status Sunan Gunung Jati sebagai wali dan sekaligus pendiri kerajaan dengan keturunannya. Perbedaan itu ditentukan oleh hierarki spasial, makam yang dimiliki oleh seorang yang berstatus paling tinggi. Makam yang terletak di tempat yang paling tinggi di kompleks makan Sunan Gunung Jati hanya raja-raja dan keluarganya yang dapat berziarah ke tingkat yang paling suci. Kasepuhan di sisi timur dan Kanoman di sisi barat memperlihatkan kesamaan statusnya yaitu setara pada tingkat VIII hingga tingkat III. Perbedaan makam antara laki-laki dan perempuan tidak ditemukan dalam makam ini, penempatan kuburan perempuan dan laki-laki dicampurbaurkan.

\section{KESIMPULAN}

Boundednes dan polusi, dengan demikian, dapat dijadikan dasar dalam melakukan interpretasi atas evidensi arkeologi. Botscharow (1991: 54) berpendapat bahwa situs arkeologi dapat dibaca sebagai teks dan hasil pembacaan dapat bermacam-macam. Hal yang penting adalah bahwa kesalahan membaca tetap memiliki kehidupan dibandingkan dengan teks yang tidak terbaca adalah benar-benar mati. Hasil pembacaan itu sendiri tidak 
terlalu penting dibandingkan dengan tindakan membaca teks itu sendiri.

Pembacaan di situs makam memperlihatkan bahwa kita dapat melihat adanya "cultural codes" dalam budaya keraton Cirebon yang membedakan antara 'yang hidup' dan 'yang mati', yang profan dan suci, tempat tinggal dan bukan tempat tinggal, Barat dan Timur. Kuburan menjadi batas spasial antara 'yang hidup' dan 'yang mati'. 'Yang mati' harus diberikan tempat yang khusus, keberadaannya tidak bersama dengan 'yang hidup'.

\section{DAFTAR ACUAN}

Ambary, Hasan. 1998. Menemukan Peradaban, jejak arkeologis dan historis Islam Indonesia. Ciputat, Tangerang : Logos Wacana Ilmu.

Botscharow, Lucy Jayne. 1991. "Sites as texts: An Exploration of Mousterian traces" dalam The Meaning of Things. Material Culture and Symbolic expression. Ian Hodder (editor). London: Harper Collins Academic, 50 - 54.

Conkey, Margaret. W. 1928. "Boundedness in Art and Society" dalam Symbolic and Structural Archaeology. Ian Hodder (editor), Cambridge, London, New York: Cambridge University Press, 115-128.

Dark, K. R. 1995. Theoretical Archaeology. Ithaca. New York : Cornel University Press.

Falah, W. Anwar. 1983. Bangunan Purbakala Sunyaragi (Cirebon). Sebuah Tinjauan Guna dan Gaya Seni Bangunan. Skripsi, Universitas Indonesia, Jakarta.

Halowell, A. Irving. 1980. "Cultural Factors in spatial Orientation" dalam Symbolic Anthropology, a reader in the study of symbols and meanings. Dolgin J. Janet et al. (editor), New York: Colombia University Press, $131-150$.

Pearson, Michael Parker. 1982. "Mortuary practices, soviety and ideology:an ethnoarchaeology Study" dalam Symbolic and Structural Archaeology. Ian Hodder (editor). Cambridge, London, New York: Cambridge University Press, 99-114.

Siddique, Sharon. 1977. Relic of the Past, A Sociological Study of the Sultanates of Cirebon, West Java, Disertasi: Zur Erlangun des Grades eines Doktor der Sozialwissenschaften an der Fakultat fur Soziologie der Universitat Bielefeld.

Shanks, Michael \& Christopher Tilley. 1982. "Ideology, Symbolic Power and Ritual Communication: A Reinterpretation of Neolotic Mortuary practices" dalam Symbolic and Structural Archaeology. Ian Hodder (editor), Cambridge, London, New York: Cambridge University Press, 99-114.

Shanks, Michael \& Christopher Tilley. 1987. Social Theory and Archaeology. Cambridge: Polity Press

Tjandrasasmita, Uka. 1998. “Dampak Perpecahan Politik di Kerajaan Cirebon kepada Penempatan Kubur Raja-raja di kompleks makam Sunan Gunung Jati, Gunung Sembung", dalam Panggung Sejarah: Persembahan kepada Prof. Dr. Denys Lombard, Henry Chambert-Loir et al. (editor). Jakarta: Yayasan Obor Indonesia, 285-300.

Woodward, Mark R. 1999. Islam Jawa, Kesalehan Normatif versus Kebatinan. Yogyakarta: LKIS. 
Peta 1

Peta Keletakan Keraton dan Makam Sunan Gunung Jati (Sumber: Falah 1983 )

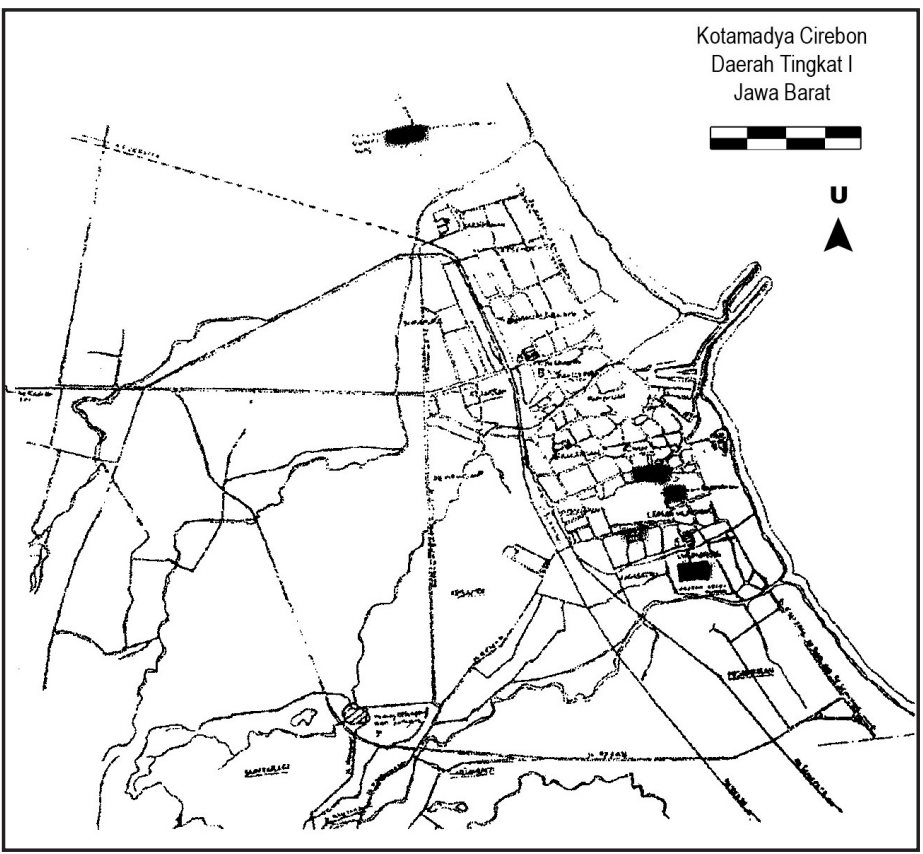

Denah 1

Kompleks makam Sunan Gunung Jati

(Sumber:Tjandrasasmita 1999)

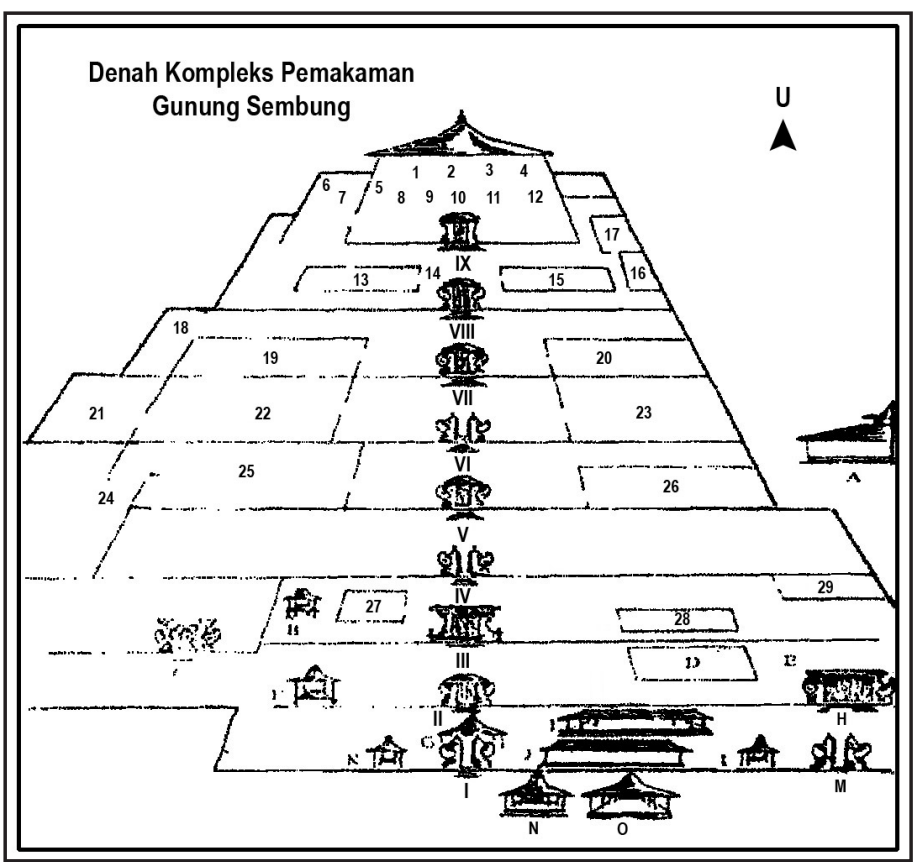

